\title{
THE STRATIGRAPHY AND DEPOSITIONAL ENVIRONMENT OF THE LATE PRECAMBRIAN GEORGEVILLE GROUP, ANTIGONISH HIGHLANDS, NOVA SCOTIA
}

\author{
J.B. Murphy \\ Department of Geology, St. Francis Xavier University \\ Antigonish, Nova Scotia B2G 1 CO \\ J.D. Keppie \\ Nova Scotia Department of Mines and EnergY \\ P.O. Box 1087, Halifax, Nova Scotia $B 3 J 2 \times 1$ \\ Date Received JulY 7, 1986 \\ Date Accepted January 2, 1987
}

\begin{abstract}
The Antigonish H1ghlands are predominantly underlain by late Precambrian rocks unconformably overlain by a limited area of Paleozoic rocks. The late Precambrian rocks are here defined as the Georgeville Group which is subdivided into several formations. In the northern highlands (Georgeville block) the succession is as follows: (1) the Chisholm Brook Formation made up of interbedded mafic volcanic rocks, marble and mudstone; (1i) the Morar Brook Formation composed of rudstone and siltstone with minor chert and 1imestone; and (11i) the Livingstone Cove Formation characterized by matrix-supported conglomerate interbedded with mudstone, chert and 1imestone. In the southern highlands (Keppoch block) the succession starts with the Keppoch Formation which is composed of calcalkalinetholelitic, subaerlal to submarine bimodal volcanic rocks interlayered toward the top with mudstone. This unit is overlain conformably to unconformably by greywackes and mudstones of the James River Formation. In the central Antigonish Highlands (Maple RIdge and Clydesdale blocks), the rocks are mainly sedimentary with minor volcanic rocks. Here, the succession is: (i) the Maple Ridge Formation composed of interbedded mudstone, siltstone and thin greywacke; (ii) the James River Formation made up of conglomerate, greywacke siltstone and shale; (ii1) the Clydesdale Formation consisting mainly of alkalic basalts interlapered with minor greywacke and shale; and (iv) the South Rights Formation composed almost entirely of shales and siltstones.
\end{abstract}

The stratigraphic sequence of the Georgeville Group suggests the progressive development of a sedimentary basin. The sedimentary rocks are interpreted as turbidites deposited in a perlare basin. Two gross 11thological trends may be discerned: (1) vertically the sequence shows an upward coarsening and thickening (progradation) followed by an upward fining and thinning (regression), and (11) laterally the grain size of the rocks decreases from north to south. These trends are interpreted in terms of a laterally migrating turbidite fan producing the observed progradation and regression with a volcanic arc source lying to the northwest. This sedimentological model is consistent with the nature of the volcanism which indicates an initial rift setting within a volcanic arc followed by oceanic island volcanism within the basin.

Les Monts Antigonish reposent surtout sur des roches tardiprécambriennes recouvertes en discordance par une zone restreinte de roches paleozoïques. On definit icl les roches tardiprécambriennes comme le Groupe de Georgeville que $1^{\prime}$ on subdivise en plusieurs formations. Dans les monts septentrionaux (bloc de Georgeville), la succession se presente comme sult: (1) la Formation de Ch1sholm Brook composee de volcanites mafiques Interlitees avec des marbres et des mudstones; (i1) la Formation de Morar Brook faite de mudstone et siltstone avec des cherts et des calcaires en faible quantite; et (i1i) la Formation de Livingstone Cove caracterisée par des orthoconglomérats interlités avec des mudstones, cherts et calcaires. Dans les monts meridionaux (bloc de Keppoch), la succession debute par la Formation de Keppoch qui comprend des volcanites bimodales calco-alcalines et tholelitiques, d'origlne subaerienne à sous-marine et s'interlitant vers le sommet avec des mudstones. Cette unite est recouverte en concordance alnsi qu'en discordance par les grauwackes et les mudstones de la Formation de James River. Au centre des Monts Antigonish (bloc de Maple Ridge et de Clydesdale), on rencontre surtout des roches sedimentalres avec peu de volcanites. Ici, on a la succession suivante: (1) la Formation de Maple RIdge composée de mudstone Interlite avec des siltstones et de minces grauwackes; (11) la Formation de James River qui comprend des poudingues, grauwackes, siltstones et argilites; (111) la Formation de Clydesdale qui consiste surtout en des basaltes alcalins interlites avec peu de $g$ rauwackes et d'argilites; et (IV) la Formation de South Rights compose dans sa presque totalite d'argilites et de siltstones.

La sequence stratiqraphique de Groupe de Georgeville suggère le développement progressif d'un bassin sedimentalre. On interprète ces roches sedimentaires comme des turbidites déposées dans un bassin péri-are. La séquence montre une organisation frustre marquee par: (1) verticalement, une granocro1ssance et une stratocroissance (progradation) sulvies d'une granodécroissance et d'une stratodécrolssance (régression), et (11) lateralement, une granodecrolssance du nord vers le sud. On croit que ces tendances sont liées à la milgration latérale d'un cône de turbidites ayant produit la progradation et la régression observées, avec comme source un are volcanique attenant au nord-ouest. Ce modele sédimentologique cadre bien avec la nature du volcantsme qui montre à l'origine un contexte de rift dans un are volcanique cedant sa place à un volcanisme d'ille océanique dans le bassin.

[Traduit par le journa1]

\section{INTRODUCTION}

The Antigonish Highlands of northeastern mainland Nova Scotia are bounded to the northwest by the northwest by the Hollow Fault, to the south by the Chedabucto Fault and to the east by Devono-
Carboniferous rocks (Fig. 1). The highlands consist predominantly of late Precambrian rocks (Georgeville Group) but also contain sequences of Cambrian-early Ordovician age (McDonalds Brook and Iron Brook Groups) and latest Ordovician-early Devonian age (Arisaig Group). 


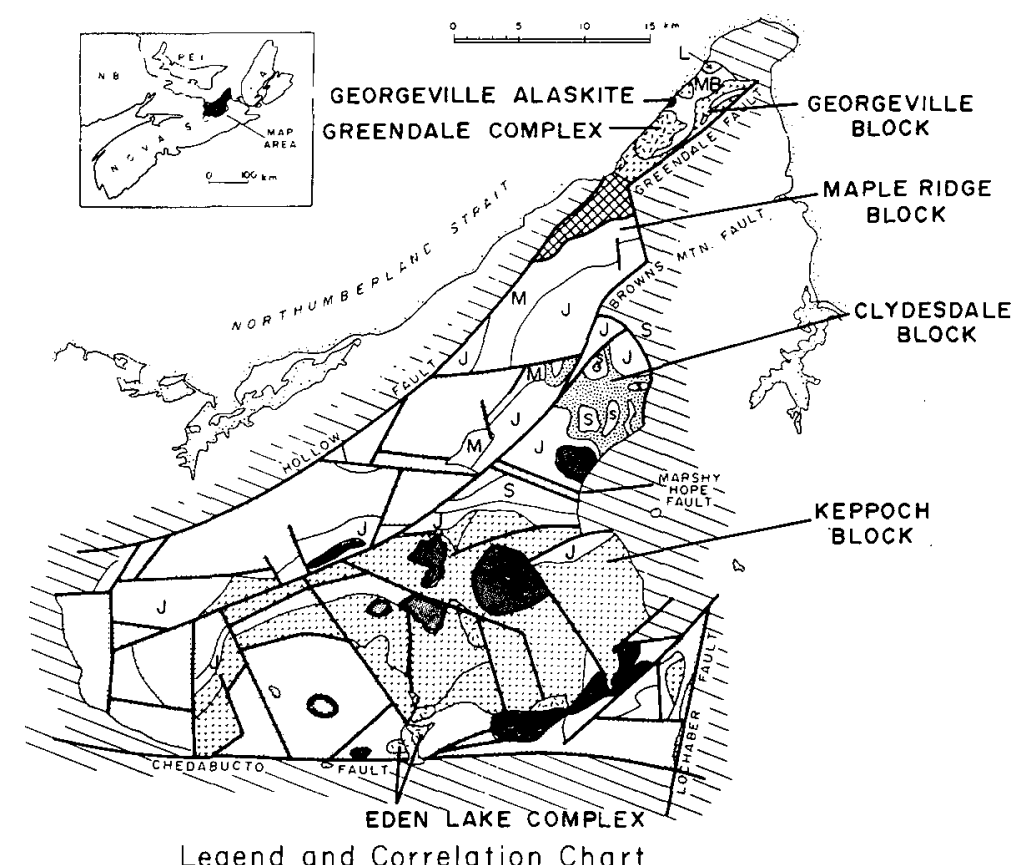

\begin{tabular}{|c|c|c|c|c|}
\hline \multicolumn{2}{|c|}{ GEORGE VILLE BLOCK } & $\begin{array}{l}\text { MAPLE RIDGE } 8 \\
\text { CLYDESDALE BLOCK }\end{array}$ & \multicolumn{2}{|c|}{ KEPPOCH BLOCK } \\
\hline $\begin{array}{l}\frac{0}{0} \\
N \\
0 \\
\frac{1}{1} \\
\square\end{array}$ & \multicolumn{4}{|c|}{$\begin{array}{l}\text { Undivided Paleozoic Rocks } \\
\text { Lote Ordovician-Eorly Devonion Rocks } \\
\text { Cambro-Ordovician Rocks }\end{array}$} \\
\hline \multirow{5}{*}{$\begin{array}{l}z \\
z \\
\alpha \\
\alpha \\
\Sigma \\
\Sigma \\
u \\
w \\
\frac{\sigma}{\alpha} \\
\alpha\end{array}$} & \multicolumn{4}{|c|}{$\square$ GEORGEVILLE } \\
\hline & & SS South Rights $\mathrm{Fm}$. & \multicolumn{2}{|l|}{ S South Rights Fm. } \\
\hline & (L) Livingstone Cove Fm. & J Jomes River Fm. & J Jomes River Fr & \\
\hline & MiB Moror Brook Fm. & $\bar{M}$ Mople Ridge Fm. & & \\
\hline & $\rightarrow$ Chisholm Brook Fm. & & \begin{tabular}{|ll}
$A$ & Moose R.Mbr. \\
$\square \Delta$ & Frosers Bk. Mbr.
\end{tabular} & $\begin{array}{l}\text { Keppoch } \\
\text { Fm. }\end{array}$ \\
\hline \multicolumn{5}{|c|}{$\begin{array}{l}\text { PLUTONIC ROCKS } \\
\text { Gronitoid rocks } \\
\text { Gobbroic rocks }\end{array}$} \\
\hline
\end{tabular}

F1g. 1. Geological map of the Antigonish Highlands simplified from Murphy et al. 1982, and Murphy, 1986.

The purpose of this paper is to define the Precambrian stratigraphy of the Antigonish Highlands. In general, it is predominantly composed of submarine deposits with relatively few volcanic rocks and contrasts with main1y continental volcanic sequences in other Avalonian terranes.

\section{PREVIOUS WORK}

Benson (1974) interpreted the Antigonish Highlands as an eugeosynclinal assemblage of probable Cambro-Ordovician age overlain by less disturbed Silurian to Devonian rocks. The CambroOrdovician Browns Mountain Group was subdivided into (i) the Keppoch Formation consisting of felsic to mafic volcanic rocks and minor phyliites overlain by (1i) the Baxter Brook Formation dominated by argilittes and greywackes, followed by (iii) the Brierly Brook Formation composed of mafic volcanic rocks and greywackes and (iv) the Little Hollow Formation consisting of red slates and iron- stones. Reconnaissance mapping by Keppie (1978) indicated that the Browns Mountain Group as defined by Benson (1974) included rocks of Precambrian to early Ordovician age and recommended the abandonment of the term Browns Mountain Group. Murphy et al. (1982) re-mapped the northern Antigonish Highlands and distinguished the Precambrian rocks (Georgeville Group) from Cambrian-Lower Ordovician rocks (Iron Brook and MacDonald Brook Groups). Subsequently, Murphy (1986) completed remapping of the Antigonish Highlands.

\section{GEOLOGICAL SETTING}

The Antigonish Highlands are divided by several large faults into four fault-bounded blocks (Fig. 1). From north to south these are: (i) the Georgeville block, (ii) the Maple Ridge block, (iii) the clydesdale block and (iv) the Keppoch block.

The style of deformation changes from polyphase to single phase across the Marshy Hope Fault which 
separates the C1ydesdale and the Keppoch blocks (Fig. 1). The three northern fault blocks show evidence of three phases of folding. $F_{1}$ folds are isoclina1, origina11y recumbent, northerly trending and easterly verging. $F_{2}$ folds are north to northeasterly trending, upright, open folds with subhorizontal fold axes and a wavelength of $5 \mathrm{~km}$. $\mathrm{F}_{3}$ folds are easterly trending, upright, open folds with subhorizontal fold axes and a wavelength of about $4 \mathrm{~km}$. The result of the superposition of these phases is a complex dome-and-basin pattern (Murphy et al., 1982). The mushroom interference pattern displayed in the C1ydesdale block indicates that the $\mathrm{F}_{1}$ fold axes are $\mathrm{N}-\mathrm{S}$ trending and that the folds verge towards the east. The $F_{1}$ and $F_{2}$ folds are late Precambrian in age because (1) their structures are truncated by late Precambrian intrusive rocks and (ii) cleaved fragments derived from the Georgeville Group occur in the unconformably overlying Cambro-Ordovician rocks. In contrast, the Keppoch b1ock is only mildiy deformed with monoclinal sequences dipping away from a central NE-SW trending anticline cored by volcanic rocks of the Keppoch Formation. The transition from polyphase recumbent structures in the Georgeville, Maple Ridge and Clydesdale blocks to mild deformation in the Keppoch block occurs rather sharply across the Marshy Hope Fault. The rocks in the three northern blocks are inferred to be within to just above a major thrust associated with the recumbent folds, whereas the Keppoch block was probably located above or below the thrust zone and is relatively little deformed. A component of vertical motion on the Marshy Hope Fault would then explain the contrasting structural styles across the fault.

The Georgeville Group is post-tectonically intruded by two major types of intrusion: appinitic (hornblende-bearing) gabbro and granite. Appinitic intrusions occur adjacent to major faults bounding the highlands: the Greendale Complex is adjacent to the Hollow Fault and the Eden Lake Complex occurs immediately to the north of the Chedabucto Fault (Fig. 1). Hornblendes from the Greendale Complex yielded a discordant $40 \mathrm{Ar} /{ }^{39} \mathrm{Ar}$ incremental release spectrum ranging from $650-600$ Ma (Murphy et al., in press), whereas a K-Ar determination on biotite in the Eden Lake Complex yielded an age of $582 \pm 32 \mathrm{Ma}$ (Wanless et al., 1967). In the absence of other 1sotopic data, and assuming that there is little or no excess argon, it is suggested that these ages represent cooling ages and provide a minimum age for the time of intrusion.

Granites intruding the Georgeville Group occur in the Georgeville, Clydesdale and Keppoch blocks but are absent from the Maple Ridge block (Fig. 1). The only age determinations are from an alaskitic granite in the Georgeville block (K-Ar on muscovite, $604 \pm 14 \mathrm{Ma}$, Wanless pers. commun., 1979; $\mathrm{Rb}-\mathrm{Sr}$ whole rock isochron, $535 \pm 13 \mathrm{Ma}, \mathrm{R} . \mathrm{F}$. Cormier written commun., 1981). The ages of the plutons in the Clydesdale and Keppoch blocks are less certain, with individual plutons producing a "best estimate" of about $520 \mathrm{Ma}$ (R.F. Cormier pers. commun., 1985).

In the northeastern highlands, Cambro-Ordovician rocks unconformab1y overlie the Georgeville Group. They have been divided into two groups that are related by lateral facies variations: the predominantly sedimentary Iron Brook Group and the predominant1y volcanic McDonalds Brook Group. The Iron Brook Group consists of 200-500 $\mathrm{m}$ of red conglomerates and slates (B1ack John Formation) overlain by $100-220 \mathrm{~m}$ of interlayered pink fossiliferous limestones and red slate and calcareous tuffs (Little Hollow Formation), followed by quartzites and fossiliferous ironstones (Ferrona Formation). Fossils in the 11mestones are late Early Cambrian in age (Landing et al., 1980) and poorly preserved inarticulate brachiopods recovered from the ironstones are probab1y late Cambrian to early Ordovician in age (Williams, 1914). Thus, it is possible that a hiatus or unconformity may exist within the Iron Brook Group.

The MacDonald Brook Group consists of $300-400 \mathrm{~m}$ of red conglomerates and slates (Malignant Cove Formation) overlain by $400 \mathrm{~m}$ of felsic tuffs, mafic, within-plate, continental flows with associated stocks (Murphy et al., 1985) and hyaloclastites with minor interlayered red slates and fossiliferous pink limestones (Arbuckle Brook Formation).

These Cambro-Ordovician rocks show varying degrees of deformation from mild deformation at the base to three phases of folding and thrusting higher in the sequence. The lowermost Silurian Beechill Cove Formation which unconformably overlies the Iron Brook Group is not affected by the $D_{1}$ and $D_{2}$ deformation, indicating a middle to late Ordovician time of deformation.

The Precambrian and Cambro-Ordovician rocks of the Antigonish Highlands are unconformably overlain by late Ordovician-early Devonian rocks of the Arisaig Group. The stratigraphy is remarkably similar to and directly correlates with that described by Boucot et al. (1974) in the type area north of the Hollow Fault. The sequence consists of subaerial red conglomerates, arkoses and shales with interlayered felsic and mafic volcanic rocks concordant1y overlain by shallow marine micaceous and fossiliferous green, black, grey and red siliciclastics with minor felsic volcanics. The fossils range in age from earliest Silurian to Early Devonian in age (Boucot et al.., 1974; Smith, 1979). These rocks are generally mildiy deformed in the Antigonish Highlands although they are locally intensely deformed adjacent to major faults.

\section{STRATIGRAPHY OF THE GEORGEVILLE GROUP}

\section{Introduction}

The Georgeville Group underlies most of the Antigonish Highlands in the Georgeville, Maple Ridge, Clydesdale and Keppoch fault blocks (Fig. $1)$. Figure 2 shows place names referred to in the text and the locations of the type sections.

The stratigraphic units in the Maple Ridge and Clydesdale blocks are similar. However, the differences between these blocks and the Georgeville block are significant enough to lead to the definition of separate formations in the Georgeville block. The type sections of three formations of the Georgevilie Group is located on the shoreline of the Northumberland Strait in the Georgeville area between Malignant Cove and Livingstone Cove. Inland, individual river sections were chosen as type sections for other formations. The formations recognized in each 


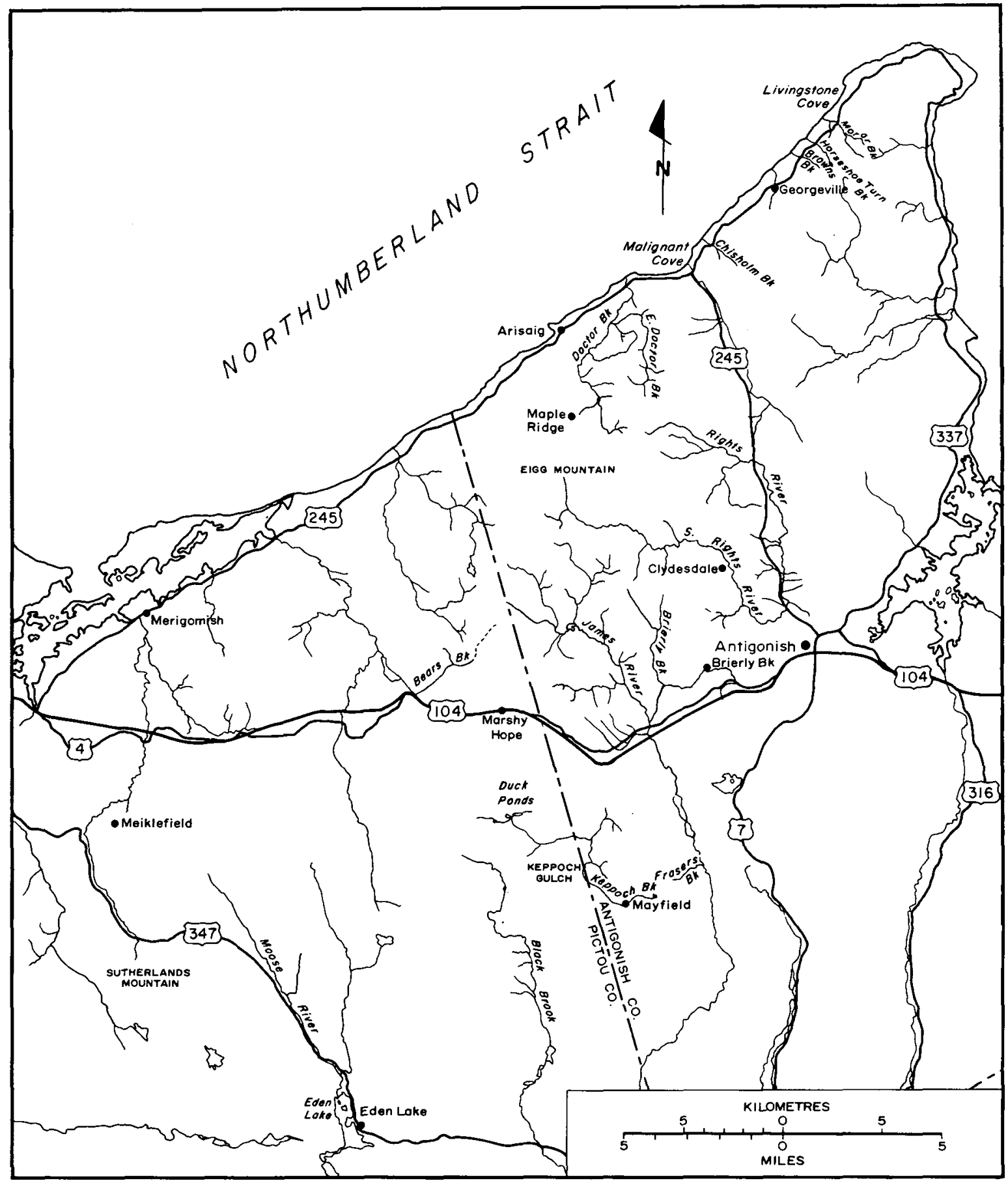

Fig. 2. Geography of the Antigonish Highlands showing-place names and locations of type sections.

block and their correlatives are given in Figure 1. Details of the location of the type sections described below are shown on the geological maps of the Antigonish Highlands (Murphy et al., 1982; Murphy, 1985). Neither the stratigraphic base nor top of the Georgeville Group is exposed in the Antigonish Highlands.
Age

Except for the recovery of an unidentifiable primitive sphaeromorph from the black mudstones of the Livingstone Cove Formation ( $\mathrm{J}$. Utting, written commun., 1977), no fossils have been found in the Georgeville Group, although numerous shale and 
mudstone samples have been analyzed for palynomorphs and several limestone samples dissolved for conodonts. Thus, the Precambrian age of the Georgeville Group must be established by other methods. No lower age limit is available. An upper age limit is established by the following relationships:

(i) in the Georgeville block, the Chisholm Brook and Morar Brook Formations were post-tectonically intruded by the late Precambrian Greendale Complex and an alaskite (Fig. 1). In the Keppoch block, the late Precambrian Eden Lake Complex intrudes the Keppoch Formation.

(ii) the Georgeville Group is unconformably overlain by the Eo-Early Cambrian rocks that occur at the base of the McDonalds Brook and Iron Brook Groups. The unconformity is exposed on Doctors Brook (Figs. 1 and 2). Although no angular discordance is visible in the field at Doctors Brook, rhyolitic tuff at the base of the northerlyfacing Iron Brook Group overlies green slates of the Maple Ridge Formation (the lowest formation of the Georgeville Group exposed in this block). Near Malignant Cove, conglomerates of the Lower Cambrian Malignant Cove Formation are inferred to rest unconformab1y on the Chisholm Brook Formation of the Georgeville Group.

Keppoch Formation

Field Relationships:

The Keppoch Formation occurs only within the Keppoch block of the southern Highlands. It is subdivided into two members based on the absence (Frasers Brook Member) or presence (Moose River Member) of finely laminated mudstones interlayered with the volcanic rocks. The type section of the Frasers Brook Member is exposed on Frasers Brook, with other good exposures on logging roads to the south of Frasers Brook, and is most accessible on logging roads in the Duck Ponds area (Fig. 2).

The Frasers Brook Member forms the core of the southern Antigonish Highlands and is flanked by successively younger rocks. The member is subdivided into sequences dominated by rhyolite, basaltic andesite and basalt though it is important to note that these distinctions are made on a percentage basis and interlayering of these lithologies occurs on all scales. The base of the member is not exposed. The upper contact with the Moose River Member is defined by the first appearance of finely laminated mudstone interlayered with the volcanic rocks. Typically, the finely laminated mudstone unit in the vicinity of the contact is 1 to $5 \mathrm{~m}$ in thickness. The Frasers Brook Member is extremely variable in thickness but consists of at least $2200 \mathrm{~m}$ of interlayered felsic to mafic volcanic rocks in the Frasers Brook area.

The Moose River Member has its type section on Moose River, and is well exposed on logging roads to the east of Moose River and in the Meiklefield area. The contact of this member with the overlying James River Formation is placed where volcanic rocks are volumetrically minor. The contact is locally conformable in the western part of the Keppoch block, where the Moose River Member is $800-1000 \mathrm{~m}$ thick. However, in the eastern part of the Keppoch block the James River Formation oversteps the Moose River Member directly onto the Frasers Brook Member.

\section{Field Description:}

The Keppoch Formation contains felsic volcanic rocks (ignimbrites, tuffs and flows), basaltic andesites, basalts, volcanigenic sedimentary rocks (such as volcanic breccias and lahars) and mudstones. Felsic rocks are massive and in the Frasers Brook Member are pink, red or pale grey in colour whereas in the Moose River Member they are generally pale green. Ignimbrites probably comprise about $50 \%$ of the felsic volcanic rocks. They are typically aphanitic or contain up to $10 \%$ plagioclase and/or quartz phenocrysts and display pale to dark red banding which is generally subparallel to bedding. Tuffs comprise about $40 \%$ of the felsic volcanic rocks and contain felsic lithic fragments up to $3 \mathrm{~cm}$ in length, but they are commonly fine grained and their tuffaceous aspect is visible only in thin section. Flows are aphyric or contain phenocrysts of plagioclase or quartz. They may be distinguished from the ignimbrites by their lack of banding but can only be reliably distinguished from the fine grained tuffs in thin section.

Basaltic andesites are grey, green-grey or pale green in colour and contain plagioclase phenocrysts up to $3 \mathrm{~cm}$ in length. The matrix is aphanitic. Basalts may be distinguished from basaltic andesites by the paucity of plagioclase phenocrysts. Basalts are massive, green to dark green, aphanitic rocks. Rarely, they contain phenocrysts of augite. They may also contain vesicles or quartz-chlorite filled amygdules. They are commonly spatially associated with mafic dykes and are best exposed in the Duck Ponds and Black Brook areas.

Lahars occur only in the Frasers Brook Member. They are composed of a distinctive purple to reddish-green matrix supporting poorly sorted angular lithic fragments up to $10 \mathrm{~cm}$ in size. Fragments consist of quartz, plagioclase, mafic and felsic volcanics. Lahars are best exposed in the Duck Ponds area.

Volcanic breccias occur at the contact between the Frasers Brook member and the overlying James River Formation. They consist of blocks of felsic to mafic volcanic rocks up to $5 \mathrm{~m}$ in diameter enclosed in a fine grained chloritic matrix. These rocks are exposed in the Keppoch Gulch area.

Finely laminated mudstones, by definition, occur on1y in the Moose River Member. They are black, grey and green, porcellaneous and are poorly cleaved. Graded bedding, load structures and CE Bouma sequences are commonly observed. These mudstones are virtually identical to those of the Morar Brook and Maple Ridge Formations in the northern Antigonish Highlands (see below).

\section{Petrography:}

Ignimbrites contain poorly sorted angular clasts of porphyritic (plagioclase) rhyolite, quartz and plagloclase and subordinate orthoclase phenoclasts In a matrix dominated by flattened to ovoid pumice. The angular shape of the clasts is common1y due to in situ brecciation. The pumice is commoniy extreme1y elongate, defines the banding and imparts 
an eutaxitic primary foliation. It is extremely variable in abundance and consists of variably sericitized quartzofeldspathic material. Pumice fragments display wispy outlines, are moulded against crysta1 and 1ithic fragments and commonly merge imperceptibly with the matrix. The remainder of the matrix is dominated by crypto-crystalline quartzofeldspathic material displaying patchy recrystallization. Secondary minerals such as sericite and chlorite, or more rarely, calcite and epidote may also be present. Sericite and chlorite display a mimetic epitaxial relationship with the primary banding.

Lithic and crystal tuffs are distinguished from ignimbrites by the lack of pumice and from flows by the clastic aspect of the matrix. The tuffs are moderately we11 sorted and massive. Lithic fragments are angular, up to $30 \mathrm{~mm}$ in length and consist of plagioclase pophyritic rhyolites, similar to the lithic clasts in the ignimbrites. Broken, angular crystal fragments of quartz and plagioclase also occur. The matrix is fine grained with a distinctive clastic texture and is predominantly quartzofeldspathic in composition. It displays incipient to extensive alteration to sericite, epidote and chlorite.

Felsic flows are generally aphyric but locally contain quartz "eyes" and plagioclase phenocrysts up to $6 \mathrm{~mm}$ in length. The matrix consists of interlocking microphenocrysts of plagioclase and subordinate orthoclase displaying crude flow textures in a fine grained quartzofeldspathic matrix. The plagloclase is commonly saussuritized and the orthoclase may be sericitized. In some instances, the matrix displays spheroidal textures. Parts of the matrix also display a patchy recrystallization to randomly oriented coarse grains of quartz and feldspar. The matrix shows incipient to extensive alteration to epidote, chlorite, sericite and biotite. Oxides are generally rare. Calcite is common adjacent to fau1ts.

Basaltic andesites contain coarse phenocrysts of plagioclase up to $20 \mathrm{~mm}$ in length. In a few phenocrysts, relict oscillatory zoning is preserved, but the plagioclase is genera11y saussuritized to albite, epidote and minor calcite. Rarely, augite microphenocrysts occur that are generally partially to completely replaced by chlorite. The matrix is dominated by albite (which displays crude flow alignment), epidote, actinolite with relatively subordinate opaques, sphene, sericite, quartz \pm calcite.

Basalts consist of microphenocysts of augite displaying incipient alteration to chlorite, and abundant laths of plagioclase (albite) defining a good flow texture. They are readily distinguished from basaltic andesites by the higher abundance of augite and opaques and by the paucity or absence of actinolite or quartz. Opaques are titaniferous magnetite or, more rarely, pyrite, and are equant to interstitial. Secondary minerals consist of epidote and chiorite. Actinolite and quartz are generally absent.

Lahars are extremely heterogenous in texture and composition. These rocks are both matrix and clast supported. Fragments are angular to sub-rounded and are poorly sorted. The fragments consist of felsic and mafic volcanic rocks that strongly resemble those of the Keppoch Formation described above except that they display moderate to strong hematitic alteration. The matrix consists of abundant hematite, chlorite and epidote with variable proportions of quartz, sericite, biotite, actinolite and carbonate.

The mudstones consist of fine grained subangular to subrounded quartz, albite and minor pyrite in a matrix dominated by sericite, chlorite and minor biotite, which define a weak cleavage generally at a shallow to moderate angle to bedding. Coarser units display graded bedding.

Environment of Deposition:

The lack of marine sediments, the weathered tops of volcanic units and the presence of welded ignimbrites indicate that the Frasers Brook Member was deposited in a subaerial environment. Thick proximal sequences of felsic or mafic volcanic rocks occur in the core of the Keppoch block whereas interlayering is typical of the extremities of the Keppoch block. This suggests a central topographic high surrounded by lower areas where both proximal and distal lavas mix.

The Moose River Member was probably deposited in a submarine environment because the mudstones and greywackes are inferred to have been deposited by turbidity currents. The fine planar laminations suggest a low energy environment of deposition, possibly at the distal end of a submarine fan model (see Walker, 1984). Individual mudstone units commonly attain a thickness of 1 to $6 \mathrm{~m}$.

\section{Chisho1m Brook Formation}

\section{Field Relationships:}

The Chisholm Brook Formation crops out only in the Georgeville block. Its type section occurs along the shoreline near the mouth of Chisholm Brook (Fig. 2). Other good sections occur in Chisho1m Brook and along the shoreline west of Morar Brook. The base of the formation is not exposed. However, the top of the formation is exposed on the shoreline near the northern margin of the Greendale Complex and at Browns Brook. At the former locality interbedded volcaniclastic rocks and mudstones grade stratigraphically upwards (the contact is overturned) into mudstones and cherts over $20 \mathrm{~m}$. The top of the Chisholm Brook Formation is placed at the top of the uppermost volcaniclastic unit clearly recognizable in the field. At Browns Brook, an $8 \mathrm{~m}$ thick mafic dyke has intruded along the contact between the volcanic-volcaniclastic rocks and the mudstonechert-limestone assemblage obscuring the original stratigraphic relationships.

The non-exposure of the base of the formation and the scarcity of way-up criteria, together with the presence of recumbent folds, make it impossible to determine the thickness of the formation. The type section exposes about $600 \mathrm{~m}$ of uniformiy dipping rocks; however, structural repetitions probably exist in this section.

\section{Field Description:}

The formation consists of metamorphosed, green, fine grained, aphyric mafic lavas and pyroclastic rocks with minor interbedded white-grey banded 
marble and dark grey mudstone. Flow boundaries were observed only where they are interbedded with marbles. Individual flows range up to $4 \mathrm{~m}$ in thickness. Pyroclastic rocks vary from lapilli tuff to volcanic breccia with fragments as large as $60 \mathrm{~cm}$ in length. They are genera11y massive and bedding is generally obscure; however, rare graded bedding is present. Adjacent to the Greendale Complex, the Chisholm Brook Formation has been thermally metamorphosed and altered (Murphy, 1982). Within the complex, some xenoliths of basalt and marble appear to retain their structural continuity with the host rocks and many are probably roof pendants. Marble horizons within the complex may be as thick as $4 \mathrm{~m}$ and vary from pure white marbles to green impure marbles.

on the shoreline west of Morar Brook, the Chisholm Brook Formation consists of numerous mafic dykes and sheets cutting fine to medium grained tuff and mafic lava. Marbles and mudstones are absent. These observations, the circular outcrop pattern and the dyke along the contact with the Morar Brook Formation suggest that this area may lie close to, or above, a vent complex. Inland exposures of the Chisholm Brook Formation are limited mainly to mafic volcanic rocks which are more resistant to erosion.

\section{Petrography:}

In thin section, primary textures are preserved in the basalts but the mineralogy is entirely secondary. The dominant minerals are albite, actinolite, epidote, chlorite, quartz and sphene \pm calcite. This assemblage is typical of the greenschist facies of metamorphism. Garnet and hornblende are common in the basalts adjacent to the Greendale Complex, and are attributed to contact metamorphism which clearly overprints the regional metamorphism.

The rocks are dominated by slender laths of albite and actinolite which generally display a rough para1lelism. Rarely, plagioclase microphenocrysts (now albite) up to $2 \mathrm{~mm}$ in length occur. They have an extremely ragged shape and are partially replaced by epidote, actinolite and chlorite. Epidote forms minute anhedral blebs and is homogeneously distributed throughout the matrix. Actinolite and calcite have an antipathetic relationship. Chlorite shows textures similar to those of actinolite, whereas calcite forms ragged grains up to $2 \mathrm{~mm}$ in length. Quartz is typically interstitial. Prehnite occurs exclusively in veins.

Dykes are spatially associated with these volcanic rocks especially in the Browns Brook area. Centres of dykes are relatively fresh and contain relict microphenocrysts of augite (partially altered to actinolite) and plagioclase (now albite) in a subophitic intergrowth, in a matrix of albite, chlorite, actinolite and quartz. One dyke contains large feldspar phenocrysts up to $10 \mathrm{~mm}$ in length which show relict zoning. The cores of these crystals contain abundant epidote whereas the rims are relatively fresh and are albitic in composition.

Marbles are saccharoidal, predominantly consisting of calcite, tremolite, serpentine (after forsterite) \pm chlorite, \pm epidote and quartz. Calcite, the most abundant phase, forms minute, ragged interlocking grains. Tremolite occurs as thin laths and is commonly partially altered to chlorite. Serpentine is generally present, forming small globular blebs and pseudomorphs after calcite. Rarely, forsterite is preserved in the centres of crystals, though is not in equilibrium with the other phases in the rock. Epidote and quartz have variable abundances, but together they generally constitute less than 5 percent of the rock by volume. Comparison of the mineralogy of these marble layers with that of the calcareous rocks in the Morar Brook Formation (discussed below) indicates that the assemblages here are due to contact metamorphism adjacent to the Greendale Complex.

\section{Environment of Deposition:}

The geochemistry of the Chisholm Brook mafic volcanic rocks suggests they were extruded during the incipient stages of rifting of a small ocean basin associated with a volcanic arc (Murphy et al.. In press). This is consistent with the shallow water environment suggested by the interbedded marble.

Morar Brook Formation

Field Relationship:

The Morar Brook Formation is restricted to the Georgeville block (Fig. 1), although it is correlated with the Maple Ridge Formation farther south. The type section of the Morar Brook Formation occurs along the Georgeville shoreline, with good sections occurring along Morar and Horseshoe Turn Brooks (Fig. 2). The Morar Brook Formation has conformable contacts with both the Chisholm Brook Formation below and the Livingstone Cove Formation above. Recumbent folding in the Morar Brook Formation precludes any estimate of true thickness; however, it has a tectonic width up to $700 \mathrm{~m}$.

\section{Field Description:}

The Morar Brook Formation consists main1y of black, grey and green porcellaneous, Iron-rich, finely laminated, poorly cleaved, fine grained mudstone and siltstone, and some thin beds of chert and limestone. Graded bedding, cross bedding, load casts and slump folds are common. $A C E$ and $C E$ Bouma sequences were observed, some of which have current reworked tops. The primary structures show that the beds face both up and down in uniformly dipping sections indicating the presence of large, tightisoclinal folds.

\section{Petrography:}

The black laminated mudstone of the Morar Brook Formation consists of fine grained, sub-angular to sub-rounded quartz, and albite with rare rutile, in a matrix that is dominated by sericite and chlorite and minor biotite. Pyrite is generally more abundant in the darker laminae and occurs in elongated aggregates. Although graded bedding is difficult to observe in the field, it is commonly visible in thin section in some of the coarser units. Matrix minerals display a strong preferred 
orientation consistently parallel to a fracture cleavage. In most cases, this orientation is also parallel to bedding. Cross-cutting relations between cleavage and bedding are rarely visible in the field. However, microscopic inspection of some of the hinge zones of minor folds shows that this relationship exists here.

The siltstones have similar petrographic characteristics, except that they are coarser grained and contain variable proportions of 1ithic fragments. The fragments are generally slate or epidote-bearing volcanic rocks. The cherts are very pure, consisting of interlocking grains of microcrystalline quartz showing undulose extinction. They may contain minor disseminated grains of pyrite.

\section{Environment of Deposition:}

The mudstones and siltstones, which make up the bulk of the Morar Brook Formation, are inferred to have been deposited by turbidity currents. The common occurrence of slump structures suggests a proximal, base of slope environment perhaps as levees or back-1evees in a submarine fan (Walker, 1984). However, the thin beds of chert and limestone suggest periods of quiet, deep water sedimentation also.

\section{Livingstone Cove Formation}

\section{Field Relationships:}

The Livingstone Cove Formation occurs only in the Georgeville block (Fig. 1). Its type section occurs along the shoreline southwest of Livingstone Cove where it rests conformably on the Morar Brook Formation (Fig. 2). The base of the Livingstone Cove Formation is defined as the first appearance of green conglomerate. This contact may be observed at several localities along the shoreline.

\section{Field Description:}

The lowest conglomerate, in common with most other conglomerates higher in the Livingstone Cove Formation, has a channeled base truncating the bedding in the mudstones. However, interbedded with the conglomerates are black mudstones and thin cherts 1dentical with to those in the underlying Morar Brook Formation, suggesting that the stratigraphic record is essentially continuous. At Livingstone Cove, the Livingstone Cove Formation is unconformably overlain by red conglomerates and sandstones of the Middle Devonian McAras Brook Formation. At this locality, the Livingstone Cove Formation is overturned and dips gently northeastwards. The McAras Brook Formation is right way up, gently dipping to the north and rests with angular unconformity upon the mudstones and siltstones of the Livingstone Cove Formation. The unconformity is displaced by a series of minor NE-trending faults.

It is difficult to determine the thickness of the Livingstone Cove Formation. Along the shoreline it has a minimum tectonic width of $700 \mathrm{~m}$, but at least three fold repetitions occur in this section and thrusting has been observed. The stratigraphic top of the Livingstone Cove Formation was not observed.
The Livingstone Cove Formation is made up of green conglomerate and greywacke interbedded with black mudstones and minor thin cherts and limestones. The conglomerates become thicker and more common higher in the stratigraphic section and are generally matrix-supported. They vary from unsorted beds with little or no internal structure. through beds displaying both inverse and normal grading and imbrication to pebbly sandstones with normal grading and cross-stratification. The clasts are usually rounded, spherical or elliptical, up to $10 \mathrm{~mm}$ in size, and supported by a sandy volcaniclastic matrix. Pebbles in the conglomerates are predominantly of volcanic origin including intermediate to felsic lava, crystal tuff and ash, granite, jasper, rose quartz, quartz and feldspar with locally derived black mudstone and siltstone.

\section{Petrography:}

With the exception of the conglomerates and associated sandstones, the rock types in the Livingstone Cove Formation are the same as those in the Morar Brook Formation; thus only the conglomerates wi1l be described here. Dacitic to andesitic pebbles are devoid of phenocrysts and consist almost entirely of thin laths of albite displaying trachytic textures, with minor quartz and albite. Rhyolitic pebbles contain phenocrysts of orthoclase, albite and chlorite enclosed in a fine grained matrix of albite, chlorite, epidote and quartz enclosed in a cryptocrystalline matrix. Some tuff clasts may be ignimbritic because they contain flattened pumice. Granite clasts commonly display graphic textures and contain quartz, plagioclase and K-feldspar. Siltstones and black mudstones comprise about half of the pebbles and have petrographic characteristics similar to those of the Morar Brook Formation. Clastic crystal fragments of albite and quartz are generally angular to sub-angular. The matrix of the conglomerates is largely clastic, consisting of angular fragments of quartz, albite, siltstone and black mudstone. However, secondary minerals such as chlorite, sericite and epidote are also common.

Greywackes are finer grained, relatively we11 sorted rocks. They are more quartz-rich than the conglomerates but contain similar clastic lithologies though in lesser abundance.

\section{Environment of Deposition:}

The conglomerates interbedded with the mudstones and siltstones in the Livingstone Cove Formation are inferred to have been deposited in submarine feeder channels near the base of the slope. The unsorted conglomerates are inferred to be debris flows deposited at a change in slope, and the graded conglomerates and greywackes were probably deposited a little farther down the channe1 (Walker, 1984). A channel deposit origin for the conglomerates may account for the lenticular shape of some of the outcrop patterns (although folding undoubtedly complicates the picture) and for the channelled bases. The interbedded slumped mudstones and siltstones, which are similar to those in the Morar Brook Formation, are inferred to have been deposited in a proximal levee or back levee environment. The upward-thickening and coarsening 
sequence suggests that the fan was prograding. The rounded nature of the pebbles in the conglomerates suggests that they were derived from shallow water gravels on a shelf. The intermediate-felsic volcano-plutonic nature of the pebbles indicates that this shelf bounded volcanic highlands of a volcanic arc. The siltstone and mudstone clasts were probably derived from the sides of the submarine canyon. The fine grained clastic sediments interbedded with the conglomerate may have been derived from the outer shelf environment at the top of the slope.

Maple Ridge Formation

\section{Field Relationships:}

The Maple Ridge Formation occurs on1y in the Maple Ridge block (Fig. 1). The type section occurs in East Doctors Brook and the formation is well exposed in the Eigg Mountain and Bears Brook area (Fig. 2). The base of the formation is not exposed, but the top of the formation, although not exposed, is closely defined by outcrops on the northernmost tributary of Rights River. The upper contact with the lower member of the James River Formation is defined by the first appearance of matrix-supported conglomerate. Where the James River Formation contains no conglomerate, the upper contact of the Maple Ridge Formation is defined by the appearance of thick greywacke sequences.

\section{Field Description:}

Typically the formation consists of finely laminated, iron-rich, procellaneous, black and green poorly cleaved mudstone and siltstone (ca. 55\%) and thin1y bedded green greywackes (ca. 40\%) in which individual beds are less than $2 \mathrm{~m}$ thick. Magnetite-rich mudstone forms a useful marker horfzon that can be traced on aeromagnetic maps (Geological Survey of Canada, 1982). Green mafic flows form a minor part of the formation. Poor exposure combined with isoclinal folding preclude any reliable estimate of the thickness of the formation, but it underlies an area about $3 \mathrm{~km}$ wide. Primary structures include graded bedding, cross bedding and slump structures. CDE, ACDE, and $A B C D E$ Bouma sequences were observed.

\section{Petrography:}

The mudstones and siltstones of the Maple Ridge Formation consist of silt- to clay-sized angular fragments of quartz and albite \pm pyrite dispersed in a matrix of sericite and chlorite, with calcite present in some of the lighter coloured laminae. It is not certain whether the albite and pyrite are detrital, authigenic or secondary in origin. One of the characteristics of the mudstones of this formation is the blocky nature of the rock where cleavage is paralle1 to bedding.

The wackes consist of angular to subangular clasts of lithic fragments (ca. 50\%), quartz (ca. $40 \%$ ) and albite (10\%) in a matrix of quartz, chlorite and epidote. The 1ithic fragments consist almost entirely of intermediate to felsic volcanic rocks. The wackes are classified as litharenites or sublitharenites.

The petrography of the mafic rocks is similar to that of the C1ydesdale Formation and will be described below.

\section{Environment of Deposition:}

The interbedded mudstones, siltstones and wackes of the Maple Ridge Formation appear to a1ternate between thinly bedded, slumped turbidites and classical turbidites. In a submarine fan mode1 (Walker, 1984) this sequence is explicable in terms of either (i) a proximal levee or back levee environment on to which a turbiditic fan pertodically encroached or (ii) a mid to lower fan environment bounded by a syndepositional fault scarp adjacent to which slumping took place. A volcanic arc source is indicated for the lithic clasts.

\section{James River Formation}

\section{Field Relationships:}

The James River Formation crops out in the Maple Ridge, C1ydesdale and Keppoch blocks (Fig. 1). The type section occurs in James River immediately southeast of the Browns Mountain Fault (Fig. 2). Other good sections occur in South Rights River and in the Mayfield area. In the Maple Ridge and Clydesdale blocks the formation is divided into two members. The lower member is defined by the presence of matrix-supported conglomerates and is bounded by the base and the top of the lowest and highest conglomerate. These conglomerates are interbedded with green shales, siltstones and wackes. The upper member is made up of wackes, siltstones and shales on $1 y$, with finer lithologies becoming predominant upwards. Matrix-supported conglomerates are rare in the Keppoch block and the division into two members could not be made.

The base of the James River Formation is not exposed in the Maple Ridge and Clydesdale blocks. Here, the boundary between the Maple Ridge and James River Formations is defined in a series of isolated outcrops in the upper reaches of the northernmost tributary of Rights River, where it is positioned between the thinly laminated mudstones (Maple Ridge Formation) apparently conformably underlying conglomerates and greywackes (James River Formation, lower member). The conformable contact between the lower and upper members is exposed in both the type section and the upper reaches of South Rights River. The upper contact of the James River Formation with the Clydesdale Formation is gradational and is placed where mafic lava flows enter the succession on South Rights River. The lower member is at least $400 \mathrm{~m}$ thick and the upper member is about $250 \mathrm{~m}$ thick for a total of at least $650 \mathrm{~m}$.

In the Keppoch block, contact between the James River and Keppoch Formations is conformable in the west but unconformable in the east. The lower contact of the James River Formation is defined where volcanic rocks are minor. In the west, this contact is gradational from subaerial volcanic rocks (Keppoch Formation, Frasers Brook Member) through submarine volcanic rocks and finely laminated mudstones (Keppoch Formation, Moose River Member) to greywackes and minor mudstones (James River Formation). In the east, the James River Formation rests directly on the Frasers Brook 
Member with the Moose River Member missing. The thickness of the James River Formation in the Keppoch block is about $2000 \mathrm{~m}$.

\section{Field Description:}

The conglomerates are very similar to those of the Livingstone Cove Formation in 1ithology and clast type. However, the pebbles are generally more rounded and smaller (up to $1.5 \mathrm{~cm}$ ). They are generally normally graded and are rarely unsorted or inversely graded. The shales, siltstones and greywackes are similar to those in the underlying Maple Ridge Formation, except that (a) slump structures are rare, (b) they are not as thinly bedded, (c) the cleavage is not as well developed, and (d) they tend to be more siliceous. The wackes are typically 1 to $4 \mathrm{~m}$ thick. In view of these similarities, no further lithologic or petrographic description is needed here.

\section{Environment of Deposition:}

The conglomerates of the James River Formation are inferred to represent channels feeding a turbidite fan. The smaller size of the clasts and the predominance of normal grading suggest that these channels were further away from the base of slope than those in the Livingstone Cove Formation. An inner fan or suprafan channel environment is inferred (cf. Walker, 1984). The interbedded wackes, siltstones and shales indicate a mid-fan environment. The thinning- and fining-upward sequence observed in the James River Formation suggests gradual regression of the fan, perhaps due to progressive change in the locus feeder channe1.

Clydesdale Formation

Field Relationships:

The C1ydesdale Formation occurs in the C1ydesdale block and the southern part of the Maple Ridge block (F1g. 1). The type section occurs in South Rights River west of Clydesdale (Fig. 2). Other good sections occur further upstream in South Rights River, in James River and in several southwesterly flowing tributarles of Brierly Brook. The base and top of the formation are exposed in South Rights River and in James River, and are defined by the first and last appearance of mafic flows interbedded with green and greywackes and shales. The mafic flows are the predominant lithology in this formation. The formation is approximately $400 \mathrm{~m}$ thick on South Rights River.

\section{Field Description:}

The volcanic units are green, aphyric, fine grained and spatially associated with maflc dykes which are difficult to distinguish from flows when contacts are not exposed. The wackes and shales are similar to those in the upper member of the James River Formation. A N-S line of positive residual total field and vertical gradient magnetic anomalies occurs over the central part of the Clydesdale Formation (Geological Survey of Canada, 1982). Unfortunately, exposure is lacking along these anomalies a1though adjacent exposures commoniy contain mafic dykes. It is possible that the anomalies represent intrusives which acted as feeders for the mafic Clydesdale volcanic rocks. The Clydesdale Formation dies out to the south where the James River Formation is conformably overlain by the South Rights Formation (Murphy, 1984). Thus, the magnetic anomalies appear to be restricted to the outcrop of the Clydesdale Formation.

\section{Petrography:}

The mineralogy of the clydesdale basalts is predominantly secondary with relict primary phases; however, primary igneous textures are commonly well preserved. Typically, basalts contain abundant thin laths and rare microphenocrysts of feldspar (now albite), exhibiting good flow textures. Microphenocrystic or subophitic augite is locally present as a relict primary phase. It displays subophitic relationships with plagioclase, but is generally partially or completely altered to chlorite and, more rarely, to actinolite. Chlorite is also abundant as a secondary phase in the matrix, where it is commonly associated with epidote and pumpellyite. Magnetite and rutile are minor accessories. Calcite is rare and tends to occur in vasicles, where it is rimmed by opaques, which in turn are enclosed by chlorite.

The petrography of the interbedded wackes and shales is similar to that of the Maple Ridge Formation and will not be repeated here.

\section{Environment of Deposition:}

The geochemistry of the Clydesdale mafic volcanic rocks suggests an ocean-island tectonic setting (Murphy et al., in press). This suggests that the interbedded sedimentary rocks were deposited in an ocean basin. The line of magnetic anomalies in the area underlain by the Clydesdale Formation may represent vent intrusions. Their linear arrangement might conceivably be related to hot spot activity beneath a moving plate, producing a gradual migration of volcanic activity with time. Alternately it could be a fault zone along which magmatism was preferentially concentrated.

\section{South Rights Formation}

\section{Field Relationships:}

The South Rights Formation crops out in the Clydesdale block, in the southern part of the Maple Ridge block and the northern part of the Keppoch block (Fig. 1). Its type section occurs in the upper reaches of South Rights River with another good section occurring farther downstream (Fig. 2). The formation consists almost entirely of green, finely laminated shales and siltstones which are common1y graded and cross bedded and display $A B C E$, $B C E$ and $C E$ Bouma units. Slump structures are absent. Rare outcrops of wacke and mafic volcanic rocks also occur. The base of the formation is placed at the top of the mafic flows. The top of the unit is not exposed. The unit is at least 400 $m$ thick in the type section and is about $200 \mathrm{~m}$ thick in the Keppoch block. In the fleld and in thin section, the sedimentary rocks are similar to those in the Maple Ridge Formation. 
Environment of Deposition:

The dominance of planar-1aminated mudstones suggests a lower energy environment of deposition than that of the underlying James River Formation. The thinly bedded character of these turbidites and the general absence of slump structures suggests either a proximal levee, back levee or a dista1 outer fan environment. The gradational contact with the underlying James River Formation in the Keppoch block (which probably has an inner fan environment) suggests that fan was regressive.

\section{CORRELATIONS WITHIN THE ANTIGONISH HIGHLANDS}

The inferred correlation among units in the varlous fault blocks is shown in Figure 3. The correlation between the Georgeville, Maple Ridge and Clydesdale blocks is based upon (a) correlation of conglomerates in the Livingstone Cove Formation with the lower member of the James River Formation and (b) the similarity of the Morar Brook and Maple Ridge Formations, and (c) the coarsening-upward sequences that are common to the lower parts of all three blocks. A1though the sequence in the Georgeville block is similar to that in the Maple Ridge and Clydesdale blocks, the following differences occur: (1) wackes, which form an integral part of most of the units in the south are rare in the Georgeville block and (2) conglomerates in the Georgeville block are coarser, thicker and more disorganized than those in the south. These differences may be explicable in terms of facles changes. It is also possible, however, that a turbidite feeder channe1 represented by the conglomerates could occur at different times in a small ocean basin.

The geochemistry of basaltic andesites in the Chisholm Brook and Keppoch Formations are remarkab1y similar and suggests correlation. Both of these sequences are unusual in that they display a similar transitional chemistry between tholeitic and calc-alkaline suites (Murphy et al.. in prep.). In the Keppoch block, the James River Formation directly overlies the Keppoch Formation. The above correlations imply that the lower part of the

\section{GEORGEVILLE BLOCK}

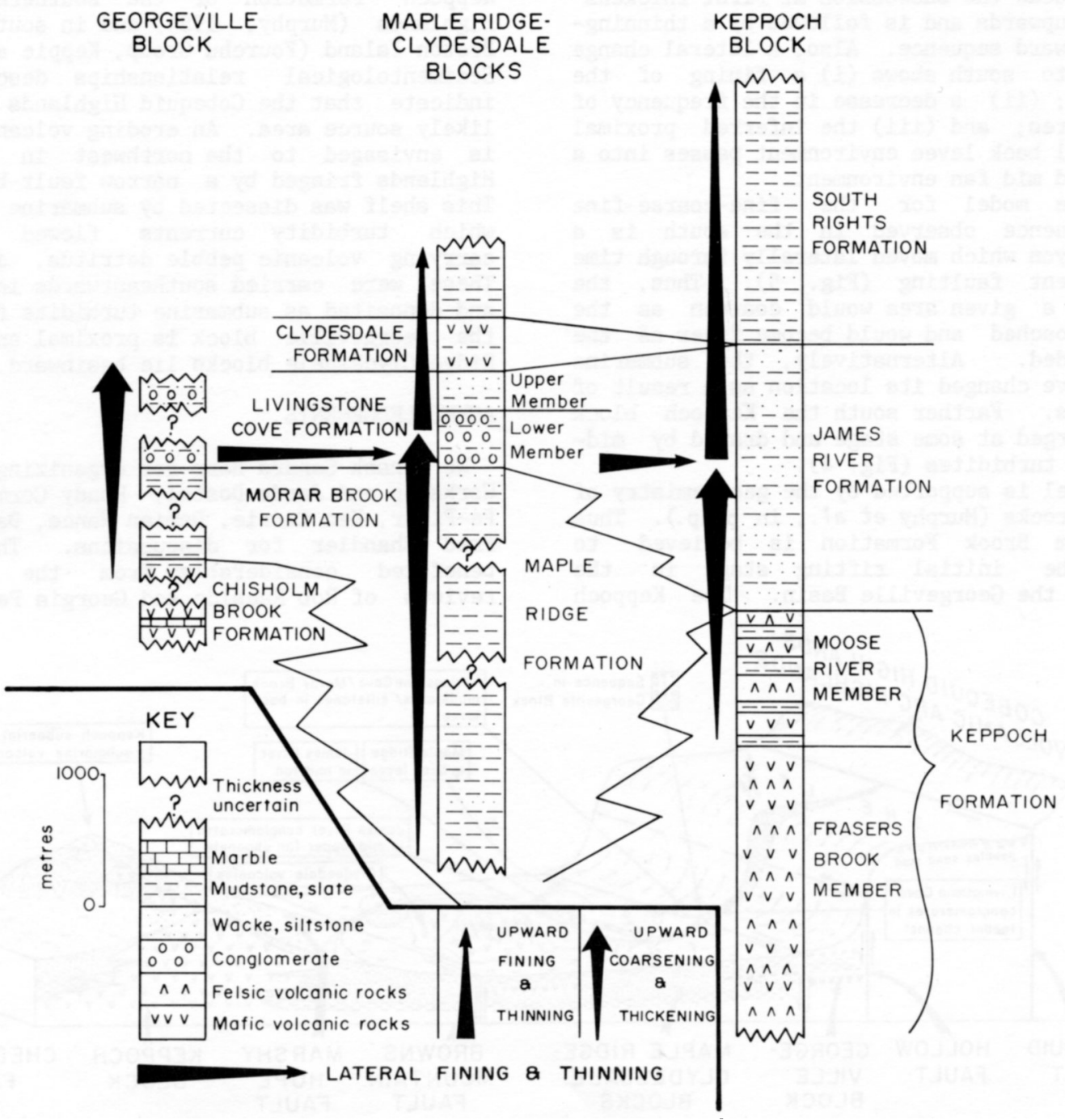

Fig. 3. Stratigraphic correlation chart for the Antigonish Highlands. Thickness of the Chisholm Brook, Morar Brook, Livingstone Cove and Maple Ridge Formations are unknown due to fold and fault repetitions. 
Keppoch Formation is equivalent to the Chisholm Brook Formation whereas the Moose River Member of the Keppoch Formation is a facies variation of the Maple Ridge and Morar Brook Formations.

\section{DEPOSITIONAL MODEL FOR THE GEORGEVILLE GROUP}

If the above correlations are accepted then it is possible to speculate on a facies mode1 for the Georgeville Group. The stratigraphy records the development of a sedimentary basin (Fig. 4). The overall distribution of the formations (although modified by deformation) supports a basin mode1 with the lowest formations occurring in the northern and southernmost blocks and the highest formations occurring in the central blocks (Fig. 1). The lowest units (Chisholm Brook and Keppoch Formations) were deposited in a shallow marine or subaerla1 environment and are overlain by a thick sequence of turbidites. The environment of deposition of the turbidites can be accommodated in Walker's (1984) submarine fan model. In the Georgeville block, the sequence thickens- and coarsens-upwards and, in the Maple Ridge and C1ydesdale blocks the succession at first thickensand coarsens-upwards and is followed by a thinningand fining-upward sequence. A1so, a lateral change from north to south shows (i) a fining of the conglomerates; (ii) a decrease in the frequency of slump structures; and (iii) the inferred proximal upper channel back levee environment passes into a more basinward mid fan environment.

A possible model for the fine-coarse-fine vertical sequence observed in the south is a submarine canyon which moved laterally through time by transcurrent faulting (Fig. 5). Thus, the sequence in a given area would coarsen as the channel approached and would become finer as the channe1 receded. Alternatively, the submarine canyon may have changed its location as a result of other factors. Farther south the Keppoch block became submerged at some stage and draped by midfan to distal turbidites (Fig. 4).

A basin model is supported by the geochemistry of the volcanic rocks (Murphy et al., in prep.). Thus the Chisholm Brook Formation is believed to represent the initial rifting stage in the formation of the Georgeville Basin. The Keppoch
Formation is transitional between a calc-alkaline volcanic arc and rifting environment whereas the Clydesdale Formation is interpreted in terms of volcanic island or seamount volcanism within the basin (Fig. 4). This model forms an integral part of the Late Precambrian tectonic model proposed by Keppie (1982a, b) in which the Georgeville Basin formed as an interarc basin within one volcanic arc which was split to form the Jeffers (Cobequid Terrane) and Fourchu (Cape Breton Terrane) volcanic arcs. Comparisons with modern volcanic arc complexes suggest that interarc basins often form as pull-apart basins in association with transcurrent faulting along the volcanic arc axis as a result of oblique convergence (Fitch, 1972).

The source area of these turbiditic sediments is uncertain due to paucity in current direction data and the effects of polyphase deformation. The composition of the pebbles indicates that the source area was probabiy a volcanic arc. Possible candidates for late Precambrian volcanic arc complexes occur in the Cobequid Highlands (Jeffers Formation) to the northwest (Donohoe and Wallace, 1980, Pe-Piper and Piper, this volume), in the Keppoch Formation of the southern Antigonish Highlands (Murphy, 1984) and in southeastern Cape Breton Island (Fourchu Group, Keppie et al., 1979). Sedimentological relationships described above indicate that the Cobequid Highlands are the more likely source area. An eroding volcanic arc source is envisaged to the northwest in the Cobequid Highlands fringed by a narrow fault-bounded shelf. This shelf was dissected by submarine canyons along which turbidity currents flowed periodically carrying volcanic pebble detritus, sand and mud. These were carried southeastwards into the basin and deposited as submarine turbidite fans, in which the Georgeville block is proximal and the Maple Ridge-Clydesdale blocks lie basinward.

\section{ACKNOWLEDGEMENTS}

We thank Sandra Barr for organizing the Avalon Workshop and Jarda Dosta1, Randy Cormier, Georgia Pe-Piper, Ken Currie, Damian Nance, David Piper and Fred Chandler for discussions. The manuscript benefited considerably from the constructive reviews of Rob Raeside and Georgia Pe-Piper. The

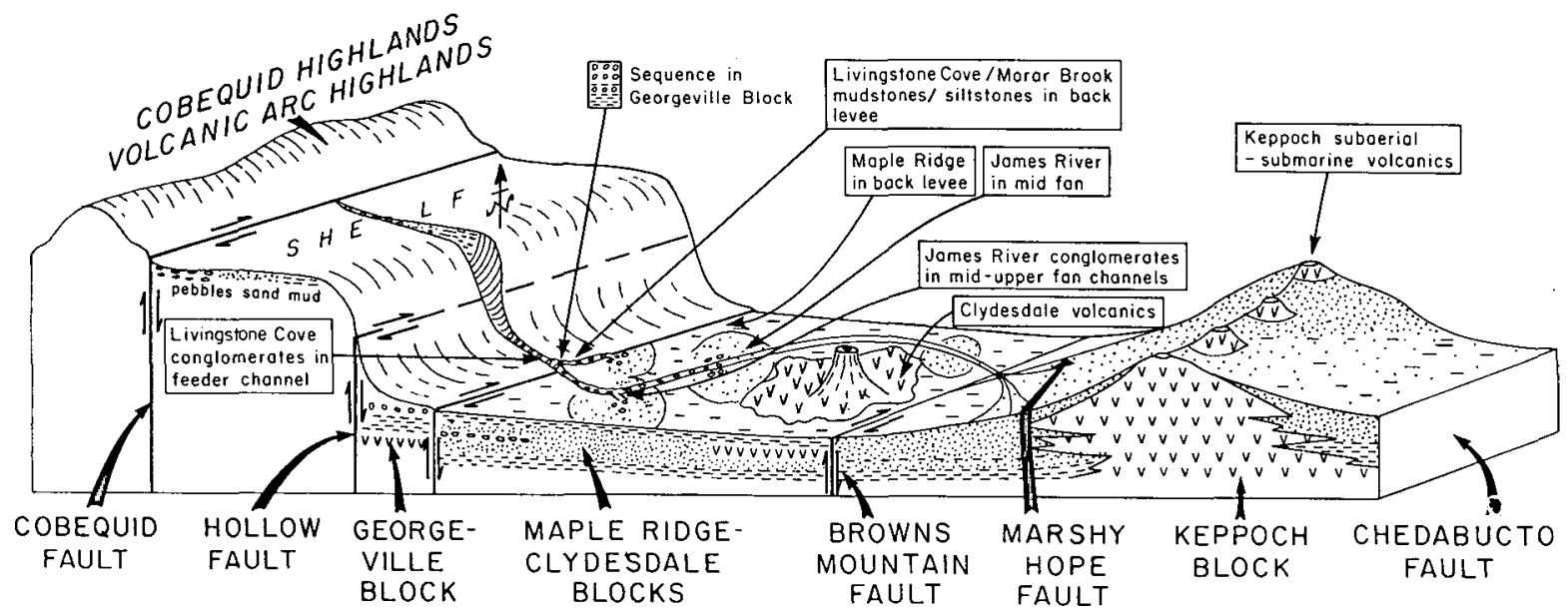

Fig. 4. Depositional model for the Georgeville Group. 


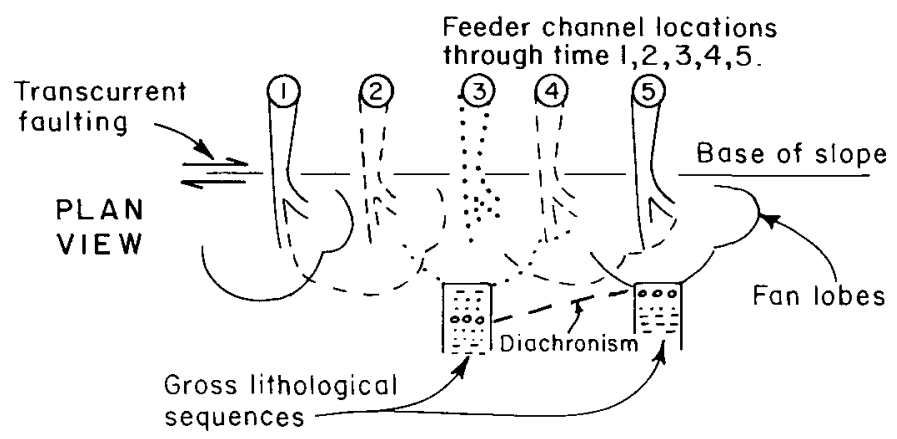

Transcurrent faulting beheads the feeder channel

The turbidite fan moves laterally through time resulting in the following succession of environments: MARGIN

BASIN

Back levee

Lower fan

Mid fan

Upper fon Suprafon

with channels

with channels

Mid fan

Back levee

Lower fan

Fine-thin

Fig. 5. Stratigraphic sequence produced by a turbidite fan progressively displaced by transcurrent faulting.

initial stages of this study were jointly funded by the Nova Scotia Department of Mines and Energy and the Department of Regional Economic Expansion. The later stages were funded by the Geological Survey of Canada and the Mineral Development Agreement and a Natural Sciences and Engineering Research Council operating grant to J.B.M. We are grateful to the Director of the Nova Scotia Department of Mines and Energy for permission to publish this paper.

BENSON, D.G. 1974. Geology of the Antigonish Highlands. Geological Survey of Canada, Memoir 376, 92 p.

BOUCOT, A.J., DEWEY, J.F. DINELEY, D.L., FLETCHER, R., FYSON,

W.K., GRIFFIN, J.G., HICKOX, C.F., MCKERROW W.S. , and ZEIGLER, A.M. 1974. Geology of the Arlsalg area, Antigonish County. Nova Scotia. Geological Society of America, Special Paper 139. $191 \mathrm{p}$.

CORMIER, R.F. 1979. Rubidium-strontiurn 1sochron ages of Nova Scotia granitoid plutons. Nova Scotia Department of Mines, Report 79-1, pp. 143-147.

DONOHOE, H.V. JR. and WALLACE, P.I. 1980. Trip 19: Structure and stratigraphy of the Cobequid Highlands, Nova Scotia. In Geological Association of Canada-Mineralogical Association of Canada, Field trip guldebook, Hallfax meeting.

FITCH, T.J. 1972. Plate convergence, transcurrent faults and internal deformation adjacent to southeast Asla and the western Pactfic. Journal of Geophysical Research, 97, pp. 4432-4460.

GEOLOGICAL SURVEY OF CANADA. 1982. Experimental colour compilation (high resolution aeromagnetic vertical gradient) of parts of $11 \mathrm{E} / 9$, 11F/5, 11F/12, Nova Scot1a. Geological Survey of Canada, Map C $40079 \mathrm{G}$.

KEPPIE, J.D. 1978. The Browns Mountain Group, Antigondsh Highlands, Nova Scotia-a preliminary re-assessment (abstract). Geologica1 Society of America, Abstracts with Programs, 10, p. 50.

KEPPIE, J. D. 1982a. The Minas Geofracture. Geological Assoctation of Canada, Special Paper 24, pp. 263-280.
KEPPIE, J.D. 1982b. Tectonic map of Nova Scotia. Nova Scotia Department of Mines and Energy Map Scale 1:500,000.

KEPPIE, J.D. . DOSTAL, J., and MURPHY, J.B. 1979. Petrology of the late Precambrian Fourchu Group in the Loulsbourg area Cape Breton Island. Nova Scotia Department of Mines. Paper $79-1,18$ p.

LANDING, E., NOWLAN, G.S. and FLETCHER, T.P. 1980. A microfauna assoclated with early Cambrian trilobites of the Callavia Zone, northern Antigonish H1ghlands, Nova Scotta. Canadian Journal of Earth Sciences, 17, pp. 400-418.

MURPHY J.B. 1984. Geology of the Southern Antigonish Highiands, Nova Scotia. Geological Survey of Canada, Paper 84-1A. pp. 587-595.

MURPHY, J.B. 1985. Geological map of the central and southern Antigonish Highlands. Geological Survey of Canada, Open File 1181 .

MURPHY, J.B. 1986. Geology of the western Antigonish Highlands, Nova Scotia. Geological Survey of Canada, Paper 86-1A, pp. 445-453.

MURPHY, J.B., KEPPIE, J.D. and HYNES, A.J. 1982, Geology of the northern Antigonish Highlands. Nova Scotia Department of Mines and Energy, Map 82-5, Scale 1:50,000.

MURPHY, J.B., CAMERON K. . DOSTAL, J., KEPPIE, J.D., and HYNES. A.J. 1985. Cambrian volcanism in Nova Scotia, Canada, Canadian Journal of Earth Sc1ences, 22, pp. 599-606.

PE-PIPER, G. and PIPER, D.J.W. 1986. Description of the late Precambrian rocks of the western Cobequid H111s, Avalon Zone, Nova Scot1a. Maritime Sediments and Atlantic Geology, 23, pp. 41-48.

SMITH, P.K. 1979. Note on the geology of new Silurian fossil occurrences, south and east of Kenzieville, Antigonish Highlands. Nova Scotia Department of Mines, Report 79-1, pp. 89-94.

WALKER, R.G. 1984. Turbidites and associated clastic deposits, In Facles Mode1s. Edited by R.G. Walker. Geoscience Canada, Reprint Series 1. pp. 171-188.

WANLESS, R.K., STEVENS, R.D., LACHANCE, G.R., and EDMONDS, C.M. 1967. Age determinations and geological studies. Geological Survey of Canada, Paper 67-2, pp. 125-129.

WILLIAMS, M.Y. 1914. Arisaig-Antigonish district, Nova Scotia. Geological Survey of Canada. Memodr 60. 